\title{
EVIDÊNCIAS DE ASSOCIAÇÕES DE FUNDO OCEÂNICO NA SEQÜÊNCIA DEPOSICIONAL ANDRELÂNDIA, SUL DE MINAS GERAIS
}

\author{
R.A.J.Trouw, R.S.Schmitt, F.V.P.Paciullo, A.Ribeiro, E.M.Oliveira Castro
}

Ao sul do Cráton do São Francisco, na zona de interferência entre as faixas móveis Brasilia e Ribeira, afloram sucessões neoproterozóicas, de margem passiva, da Seqüência Deposicional Andrelândia (Paciullo et al., 1992). Este trabalho refere-se à porção distal desta seqüência, na região de Liberdade-Carvalhos (MG). $\mathbf{O}$ objetivo é demonstrar, com o apoio da litogeoquímica, que a íntima associação de gnaisses, anfibolitos e granada-quartzitos, de fácies anfibolito alto a granulito, caracteriza um paleoambiente de fundo oceânico.

Para este estudo foi descrito um perfil de cerca de 80 metros, a $2 \mathrm{~km}$ ao norte de Carvalhos (MG). Nos 30 metros basais ocorre um gnaisse com bandas de espessura centimétrica, reconheciveis por conterem diferentes proporções de anfibólio e biotita. Acima ocorre, no mínimo, 20 metros de um cianita-granada-K-feldspato-biotita-gnaisse homogêneo. A zona de transição, com 20 metros de espessura, é marcada por alternâncias de camadas até decimétricas dos dois tipos de gnaisse. Corpos de anfibolitos, com no máximo 3 metros de espessura, se intercalam nesta sucessão, especialmente na zona de transição. Camadas de espessura centimétrica de granada-quartzitos associam-se, preferencialmente, aos corpos anfibolíticos.

Neste tipo de sucessão, os gnaisses bandados podem ser interpretados como turbiditos de acamamento delgado, os gnaisses homogêneos, como depósitos pelágicos, enquanto os anfibolitos representariam derrames basálticos. $\mathbf{O}$ granada-quartzito é considerado como um depósito do tipo chert, associado à interrupção na sedimentação pelítica, induzida pelas efusões básicas.

Para verificar esta interpretação, em particular das rochas máficas, foram analisadas sete amostras, cinco delas coletadas no perfil descrito e duas em afloramentos próximos. As análises de elementos maiores, menores e terras raras foram feitas no GEOLAB GEOSOL.

Segundo os critérios de Leake (1964), os anfibolitos têm características de rochas orto-derivadas. As análises plotam no campo dos basaltos subalcalinos toleíticos dos diagramas de Irvine \& Baragar (1971). Já nos diagramas discriminantes geotectônicos elaborados por Pearce \& Norry (1979) e Pearce \& Cann (1973), concentram-se próximo ao limite dos campos dos basaltos intraplaca e de cadeia meso-oceânica. Isto, aliado ao enriquecimento em LREE, sugere que estes basaltos atravessaram crosta continental adelgaçada.

Gonçalves \& Figueiredo (1992) e Paciullo (1992) chegaram a conclusões semelhantes, analisando outros anfibolitos na mesma bacia.

Departamento de Geologia, Universidade Federal do Rio de Janeiro. 


\section{Referências Bibliográficas}

GONÇALVES, M.L.; FIGUEIREDO, M.C.H. (1992) Geoquímica dos anfibolitos de Santana do Garambéu (MG): implicações sobre a evolução do Grupo Andrelândia. Geochimica Brasiliensis, v.6, n.2, p.127-140.

IRVINE, T.B.; BARAGAR, W.R.A. (1971) A guide to the chemical classification of the common volcanic rocks. Canadian Journal of Earth Sciences, v.8, p.523-548.

LEAKE, B.E. (1964) The chemical distinction between ortho- and para-amphibolites. Journal of Petrology, v.5, n.2, p.238-254.

PACIULLO, F.V.P. (1992) Orto-anfibolitos no Ciclo deposicional Andrelândia - assinatura química e ambiente tectônico. In: CONGRESSO BRASILEIRO DE GEOLOGIA, 37. São Paulo, 1992. Boletim de Resumos Expandidos. São Paulo, SBG, v.2, p.28-29.

PACIULLO, F.V.P.; RIBEIRO, A.; ANDREIS, R.R. (1993) Reconstrução de uma bacia fragmentada: caso do Ciclo deposicional Andrelândia. In: SIMPÓSIO SOBRE O CRÁTON DO SÃO FRANCISCO, 2., Salvador, 1993. Anais. Salvador, SBG, v.1, p.224-226.

PEARCE, J.A.; CANN, J.R. (1973) Tectonic setting of basic volcanic rocks determined using trace element analysis. Earth Planetary Science Letters, v.19, p.290-300.

PEARCE, J.A.; NORRY, M.J. (1979) Petrogenetic implications of $\mathrm{Ti}, \mathrm{Zr}, \mathrm{Y}$ and $\mathrm{Nb}$ variations in volcanic rocks. Contributions to Mineralogy and Petrology, v.69, p.33-47. 